NBER WORKING PAPER SERIES

\title{
USING OPTIONS TO DIVIDE VALUE IN CORPORATE BANKRUPTCY
}

\author{
Lucian Arye Bebchuk \\ Working Paper 7614 \\ http://www.nber.org/papers/w7614 \\ NATIONAL BUREAU OF ECONOMIC RESEARCH \\ 1050 Massachusetts Avenue \\ Cambridge, MA 02138 \\ March 2000
}

William J. Friedman and Alicia Townsend Friedman Professor of Law, Economics, and Finance; Research Associate, National Bureau of Economic Research. This paper was prepared for presentation in the 1999 Congress of the European Economic Association and I am grateful to participants in my session for their comments. The paper is part of a larger project on the options approach to corporate bankruptcy, and in pursuing this project I have benefited from the many comments and reactions that I have received over the years since the publication of my 1988 article. Finally, for financial support, I am grateful to the NSF and to the John M. Olin Center for Law, Economics, and Business. The views expressed herein are those of the authors and are not necessarily those of the National Bureau of Economic Research.

(C) 2000 by Lucian Arye Bebchuk. All rights reserved. Short sections of text, not to exceed two paragraphs, may be quoted without explicit permission provided that full credit, including (C) notice, is given to the source. 
Using Options to Divide Value in Corporate Bankruptcy

Lucian Arye Bebchuk

NBER Working Paper No. 7614

March 2000

JEL No. G3, G33, K2

\title{
ABSTRACT
}

This paper revisits the proposal to use options in corporate bankruptcy that was put forward in Bebchuk (1988). According to the proposed procedure, corporate bankruptcy should be implemented through the distribution to participants of appropriately designed options. The paper starts by discussing the goals that should guide the design of bankruptcy procedures. The paper then explains how the options procedure can improve both ex post efficiency and ex ante efficiency. The paper offers a refined version of the procedure, and it also responds to questions that have been raised regarding the execution and desirability of the procedure. The paper concludes by explaining the relationship between the options approach to corporate bankruptcy and the Black-Scholes characterization of all corporate securities as options.

\author{
Lucian Arye Bebchuk \\ Harvard Law School \\ Harvard University \\ Cambridge, MA 02138 \\ and NBER \\ bebchuk@law.harvard.edu
}




\section{Introduction}

Reorganization is one of the two routes that a corporation in bankruptcy may take. When a corporation becomes insolvent and bankruptcy proceedings are commenced, the corporation will be either liquidated or reorganized. In liquidation, the assets of the corporation are sold, either piecemeal or as a going concern. The proceeds from this sale are then divided among all the participants -- all those that hold claims against or interests in the corporation. In contrast, in a reorganization, there is no actual sale of the company's assets. Instead, there is an "hypothetical" sale of the company to the existing participants -- they "pay" for the company with their existing claims and interests, which are canceled, and they receive in exchange "tickets" in the reorganized company (that is, claims against or interests in this new entity). In the US, when large publicly-traded companies become insolvent, they usually pursue the reorganization route.

In an earlier work (Bebchuk (1988)), I have put forward a new bankruptcy procedure for corporate reorganization based on the use of options. The options scheme can, despite the fact that the value of a reorganized company is likely to be nonverifiable by courts, implement quickly the contractually prescribed distribution of the reorganization pie. The proposed procedure has received some significant support in subsequent literature; for example, it was adapted as the basis for bankruptcy reform in the well-known proposals by Aghion, Hart, and Moore (1992) (and subsequently by Hart (1995) and Hart et al. (1997)). The procedure has also received its share of critical or skeptical reactions. In this paper I revisit the options proposal. The paper offers a refined version of the procedure, incorporating some of the suggestions that have been made, restates the case for it, and respond to some questions and objections that have 
been raised over the years. ${ }^{1}$

The paper starts by discussing in Section 1 the two goals - of ex post and ex ante efficiency - that should guide the design of efficient bankruptcy procedures. Section 2 explains why a bargaining-based procedure, such as the one provided by Chapter 11 of US law, cannot serve well these two goals. Section 3 describes how the refined version of the option procedure would operate. Section 4 demonstrates and discusses the effectiveness of the proposed procedure. In the course of their analysis, Sections 3 and 4 address some of the questions that have been raised concerning the execution and desirability of the procedure. Finally, Section 5 explains, also responding to questions that have been often raised, the relationship between the options approach to corporate reorganization and the Black-Scholes characterization of all corporate securities as options ${ }^{2}$.

\section{Two Goals for Bankruptcy Procedures}

From an efficiency perspective, there are two objectives that bankruptcy rules - and the rules governing corporate reorganization in particular - should serve. ${ }^{3}$

(i) Ex post Efficiency = Maximization of the value of the reorganized company. Ex post,

\footnotetext{
${ }^{1}$ Bebchuk (1999) seeks to address all the questions that have been raised about the proposal. This short paper attempts to deal only with a few of them.

${ }^{2}$ One subject that is beyond the scope of this short paper is a full comparison between the options procedure and auctions. Supporters of auctions (see Baird (1986), Jensen (1991)) propose that the assets of an insolvent firm be always auctioned. Critics of auctions worry that they might not generally enable capturing the full value of the assets. For example, Shleifer and Vishny (1992) argue that, when a firm becomes insolvent, other firms in the industry, which are natural potential buyers, are likely to face liquidity problems. While a full comparison is beyond the scope of this paper, it will be observed that under the option procedure each participant would fare at least as well as (and possibly better) than under an auction if the auction were to take place at the same time as the exercise of the auctions.

3 See Bebchuk (1998a). While the division of the bankruptcy pie might be also guided by fairness considerations and the options scheme might be also helpful in this regard, the current paper focuses only on efficiency considerations.
} 
given that the company has entered insolvency proceedings, it is desirable, other things equal that the total value of the assets - the total value that will be distributed among the participants will be maximized. There are two elements to this objective. First, as little value as possible should be dissipated during the reorganization process; to this end, it is desirable to minimize the time that the process will take and the direct and indirect costs incurred during this process. Second, when the reorganization process ends, the company's assets will be allocated to their highest-valued use.

(ii) Ex ante Efficiency = Optimal division of total value. From an efficiency perspective, what matters is not only that the total bankruptcy value will be as large as possible but also how this value will be divided among the participants. This ex post division has important ex ante consequences. In particular, to induce participants to provide finance to the company ex ante, it is desirable that, in the event of ex post insolvency, the value will be divided according to the distribution or ranking of priorities that were agreed upon contractually.

3. The Problems of the Bargaining-Based Approach

\subsection{The Valuation Problem}

A major problem that reorganization rules face concerns valuation -- the difficulty inherent in estimating the value of the reorganized company. Note that a problem of valuation does not exist in liquidation when an actual sale to an outsider takes place. The liquidation results in an exchange of the company's assets for cash (or cash equivalents). Whether or not this cash represents the true value of the assets sold, there is no question as to what is the total value that is available for distribution. The receiver running the liquidation thus can proceed by paying 
creditors according to the ranking of their claims until all the money runs out.

In contrast, the sale of the company's assets in a reorganization is fictional. Consequently, no verifiable, objective figure is available for the total value to be distributed and, as a result, also for the value of the various tickets in the reorganized company. The nonverifiability of the reorganization value is likely to lead participants to advance different estimates even if their true estimates are the same or differ little. Senior creditors have a strategic incentive to advance a low valuation, because a low valuation would entitle them to a larger fraction of the tickets in the reorganized company. For a similar reason, equityholders have a strategic incentive to advance a high valuation.

The way in which the law of the US, and most other countries that have a reorganization process, has dealt with this problem of valuation is by leaving the division of value to a process of bargaining among the classes of the participants. The law has sought only to provide a set-up for this bargaining process and to establish constraints within which the division must take place. Under the rules governing US reorganizations (usually referred to as "Chapter 11"), a plan of reorganization will generally be confirmed if all the classes of participants approve it. Because the objection of any class of participants makes confirmation of a reorganization plan more difficult, the designers of reorganization plans commonly seek to get the approval of all classes. As explained below, this bargaining-based procedure does not perform well in terms of either $e x$ post or ex ante efficiency.

\subsection{How Bargaining Leads to Ex post Inefficiency}

(i) The dissipation of value during the reorganization process: The reorganization process under the existing bargaining-based rules takes substantial time (see e.g., Lopucki and Whitford (1990), Weiss (1990)). During this time, substantial value might be dissipated. To begin with, the 
Chapter 11 process involves substantial administrative costs (see Cutler and Summers (1988)).

Second, and more importantly, the company under reorganization might incur substantial "indirect" costs from functioning inefficiently during the lengthy reorganization process. Because the managers might not face good incentives and market discipline, management decisions during the process are likely to be distorted. And potential business partners may be reluctant to deal with the company, or may demand especially favorable terms, as long as the insolvency cloud hovers above the company. The indirect costs are large because of the substantial delay produced by the bargaining process.

(ii) Potential inefficiencies in the structure emerging out of the process: There are reasons to suspect that inefficiency costs might be incurred even after the bargaining process ends, because the structure emerging out of the process might not be optimal. For example, White (1994) suggests that the existing process is biased in favor of continuation -- that is, the company is likely to continue as a going concern even if the most efficient route would be liquidation. This argument is consistent with the empirical evidence that companies emerging out of reorganization often go through another financial restructuring within the subsequent few years (see Hotchkiss (1995)).

\subsection{How Bargaining Leads to Ex ante Inefficiency}

The existing bargaining-based approach leads to a division of value that often deviates from the division that is prescribed by the participants' contractual rights. What each class gets under the existing process depends not only on the value to which it is contractually entitled but also on the various factors that affect the strength of its bargaining position under the existing rules. 
In particular, because the equityholders can often block or at least delay the approval of a plan, they will have some bargaining power even when the value of debt exceeds the total reorganization value. Bebchuk and Chang (1992) develop a model of the bargaining under the existing rules that identifies three reasons as to why equityholders might be able to extract value even when creditors are not paid in full. The deviations in favor of equityholders that the bargaining process produces are well documented by empirical work -- work indicating that, even when creditors are not paid in full, equityholders are often able to extract significant value (see, e.g, Eberhart, Moore and Roenfeldt (1990), Franks and Torous (1989), and Weiss (1990).

\section{The Options Procedure for Corporate Bankruptcy}

Let us now turn to describing how the options procedure will operate. ${ }^{4}$ Consider a company $\mathrm{C}$ that entered into corporate reorganization proceedings. While the options approach can in principle be applied to any company, it is especially fitting for publicly traded companies, and it will be assumed that $\mathrm{C}$ is such a company. According to the options approach, the procedure should proceed in accordance with the following stages:

Stage 1: Determination of the various classes of participants.

Stage 2: Distribution of appropriately designed options.

Stage 3: Exercise of the options -- which would allocate all the securities of the reorganized company.

Stage 4: Decision by the shareholders of the reorganized company about the future course of the company.

4 This Section offers a refined version of the main elements of the procedure. See Bebchuk (1988) for discussion of some needed additional elements, including the treatment of security interests, outstanding contracts with favorable terms, and concentration of claims in one hand. 


\subsection{Stage 1: The Participants}

Suppose that the participants in the reorganization are grouped into $\mathrm{n}$ classes. Each class $\mathrm{i}$ has $\mathrm{m}_{\mathrm{i}}$ equal units of participation (two or more units of participation might be of course owned by one agent). It will be assumed that each unit of a given class provides the unit's owner with the same entitlement in bankruptcy.

The reorganized company, which will be called $\mathrm{RC}$, is going to have a given capital structure. One version of the option procedure would have the reorganized company start initially with an all-equity structure. Such a restriction should not be regarded as problematic; if another capital structure is superior to an all equity structure, it can be expected that at Stage 4, when the new shareholders will be able to make efficient choices for RC, they will move to the optimal structure. Another version of the option procedure would have the capital structure of $\mathrm{RC}$ set by an expert (say, an investment banker) chosen by the supervising court. If this expert does not choose the optimal capital structure, then again the shareholders would likely replace it once the securities of $\mathrm{RC}$ are distributed. Whatever is going to be the capital structure of RC, it will be possible to divide the securities of RC available for division into equal units. Let us denote by s the number of units of RC's securities that will be available for division among the participants.

The total value of the (s units of) securities of RC to be distributed among the participants is $\mathrm{V}$. The question for the reorganization process, and for the options procedure, will be how to divide $\mathrm{V}$ among the participants. The desirable division of value (assuming that $\mathrm{V}$ is known ) is given by the ex ante contractual terms agreed upon by the participants. (If some of the creditors are involuntary (such as tort creditors), the desirable division would be the one prescribed by law for these creditors.) We shall assume that the contractually specified distribution is sequential. In 
a sequential distribution, classes are ranked, and any given class is entitled to get some value only after higher-ordered classes have been paid in full. Bebchuk (1998b) shows how the options procedure can be adjusted to implement contractually prescribed distributions that are not sequential - for example, distributions under which the equityholders are supposed to get some value even if the debtholders are not paid in full.

Specifically, let us suppose that any given class i should get value only after classes $j<i$ have been paid in full. The full payment needed to satisfy the claims of each class $i$ is $D_{i}$. The last class, $n$, is a class of equityholders. For this class $n$, the residual claimant, we can define $D_{n}$ $=\infty$. For each class $i$, let us also denote by $\bar{D}_{\mathrm{i}}$ the total value of the claims of the classes above it; that is, $\bar{D}_{i}=\sum_{j=1}^{i-1} D_{j}$.

Thus, under the desired distribution, each class i is entitled to get value only if $V>\bar{D}_{\text {i }}$. Also, no class i should get a value exceeding $D_{i}$ nor (given limited liability) a value below 0 . Thus, the value to which a class $i$ is entitled is $E_{i}=\min \left[D_{i}, \max \left(O, V-\bar{D}_{i}\right)\right]$. As to members of class $i$, for each one of the $m_{i}$ units of class $i$, the owner of the unit is entitled to a value of $\left(1 / \mathrm{m}_{\mathrm{i}}\right)$ $\mathrm{E}_{\mathrm{i}}$.

In describing the operation of the procedure, it will be helpful to use at times a simple example. In the example to be used, RC has three classes of participants: a class of 100 senior claims, each owed 1; a class of junior creditors, each owed 1; and a class of 100 equityholders, each holding one unit of equity. And suppose that the reorganized company RC is going to have 100 units of securities with a total value of $\mathrm{V}$. In this case, if $\mathrm{V}<100$, then each senior creditor is entitled to V/100 and junior creditors and equityholders should get 0 . If $200>V>100$, then senior creditors are entitled to 1 each, junior creditors are entitled to V-1 each, and equityholders should 
get 0 . Finally, if $V>200$, senior and junior creditors should get 1 each, and equityholders should get V-2 each.

\subsection{Stage 2: The Options to be Distributed}

If $\mathrm{V}$ were verifiable by courts, then we would have no problem in deciding how to divide the securities of RC among the participants to accomplish the contractual distribution of $\mathrm{V}$. However, $\mathrm{V}$ is not verifiable by courts, and the question is how to implement the desired distribution given that $\mathrm{V}$ is not verifiable. The idea behind the option procedure is to divide the securities through the distribution to participants of options that are so designed that no participant would have a basis for complaining about receiving less than the value to which he is entitled.

At Stage 2, the options are to be distributed. Under the proposed method, the units of RC's securities will not be distributed to the participants right away but instead they will be held by a "clearing agent" (CA). The participants will get certain rights (options) with respect to RC's securities held by the CA, and the participants' decisions concerning the exercise of their rights will determine the ultimate distribution of RC's units. As will be explained below, CA will not have any discretion -- it will follow mechanically a prescribed procedure in responding to participants' exercise decisions.. Accordingly, the function of serving as a CA can be assigned to an office of the company RC (as was assumed in the 1988 proposal), to a clerk of the supervising bankruptcy court, or to some hired outside party.

The critical aspect of the method, to which we will now turn, is the setting of the terms of the options. In the simple three-class example introduced above, the options would be set as 
follows. There will be three types of options. Each senior creditor will receive one type-1 right. Under certain circumstances described below, a type-1 right will be redeemed by the CA at Stage 3 for a value of 1 . If the right is not redeemed, however, its holder would be entitled to receive at Stage 3 one unit of RC.

As to the junior creditor, each will receive one type-2 right. Under certain circumstances, type- 2 rights will be redeemed by the CA at Stage 3 for 1 . If the right is not redeemed, its holder would have the option to purchase one unit of $\mathrm{RC}$ for 1 . If the holder of the right would like to exercise this option in the event that the right is not redeemed, the holder would have to submit such a request to the CS by the time of Stage 3 .

Finally, each equityholder will receive one type-3 right. A type-3 right may not be redeemed by the $\mathrm{CA}$. The holder of such a right will have at Stage 3 the option to purchase one unit of RC for 2. Again, to exercise this option, the holder would have to submit an exercise request to the CA by Stage 3 .

In the more general case of $\mathrm{n}$ classes, there will be $\mathrm{n}$ types of rights. The members of class i will get all the type-i rights. Each class of rights will include s (divisible) units to be divided among the members of the class, $\left(\mathrm{s} / \mathrm{m}_{\mathrm{i}}\right)$ type-i rights for each unit of class $\mathrm{i}$. Under certain circumstances to be described below, type-i rights will be redeemed by the CA for a certain price -- a price equal to $\mathrm{D}_{\mathrm{i}} / \mathrm{s}$, the per right prorata amount "owed" to class $i$. If the right is not redeemed, its holder will have the option to purchase one unit of RC for a price equal to $\bar{D}_{\mathrm{i}} / \mathrm{s}$, the per right amount "owed" to classes above i. A holder of a type-I right who will wish to exercise the option to purchase one unit of RC in the event that the right will not be redeemed will have to submit their rights to the CA by Stage 3 (accompanied by an appropriate commitment to pay the exercise price). 
Stage 3 should in principle come as soon as practicable after Stage 2. Because participants might need a little bit of time to understand the terms of the options given to them and to decide whether to exercise the options included in them, it might be desirable to provide them with such time -- say, a month. In this interim period between Stages 2 and 3, rights will be transferable and trading in the rights is thus likely to take place.

\subsection{Stage 3: Exercising the Options}

The exercise decisions that the holders of rights will make by Stage 3 will determine how CA will distribute all the units of RC among the holders of rights. Given how the terms of the distributed rights are set, the CA will always distribute all the units of RC in a way that will fully respect the terms of the distributed rights. The reason for this is that the terms of the options will be set so that the net obligation of the CA toward all those that will submit options will always add up to the s units of RC that the CA will have available for distribution.

To illustrate this point, consider the three-class example used above, and consider the three main possible scenarios. Suppose first that all of the holders of type-3 rights wish to exercise their options. In this case, CA will provide them with all the 100 units of RC (one unit for each right submitted) and will use the 200 received from them to redeem all of the type- 1 and type-2 rights. Suppose next that no type-3 rights are submitted for exercise, but that all holders of type-2 rights wish to exercise them. In such a case, CA will give all of the $\mathrm{RC}$ units to these holders of type- 2 rights, and it will use the 100 received from them to redeem all of the type- 1 rights. Finally, suppose that no type-3 or type-2 rights are submitted for exercise: in this case, all of the units of RC will be distributed to the holders of type-1 rights. ${ }^{5}$ 
Stage 4: The Post-exercise Course of Action

Once the options are exercised, the company will be out of the insolvency process and will have a body of shareholders. During the insolvency process, efficient decision-making about what to do with R's assets cannot take place because it is not clear who owns the assets. But once the assets are removed from insolvency to a "normal" corporate structure, their allocation will no longer be subject to the distortions arising from insolvency. As is the case with any new company, shareholders will choose directors among whatever rivals teams (offering alternative plans and qualifications) will compete. The shareholders - and the directors chosen by them will have an incentive to take that course of action - continuation, strategic reorientation, partial or full liquidation, etc. - which would maximize company value.

The contribution of Aghion, Hart, and Moore (1992) to the options procedure was in their suggestion to add a formal process of choosing among "bids" at stage 4 . They proposed that shareholders will be offered cash or non-cash bids (the latter might be just offers to run the company with the shareholders retaining their shares) and will vote to choose one among them. The value of this addition does not lie in having the shareholders vote to choose among alternatives. Even without this special procedure, the shareholders would be essentially making such a choice when electing the first directors; the vote on the first directors would represent a choice among the alternative plans put forward in the proxy materials of the managers seeking to be elected (including possibly plans to sell to a given potential buyer for a given price). Rather,

\footnotetext{
5 The above scenarios are ones in which at Stage 3 holders of all rights of a certain type act in the same way. Given that the rights are going to be traded, this is indeed likely to be the case: if some holders of rights do not wish to exercise them while others do wish to do so, the former should be willing to sell their rights and the latter should be willing to buy them. But it should be emphasized that the CA would have no problem respecting all the rights and distributing all the units of $\mathrm{RC}$ in scenarios of partial submission of rights of
} 
the Aghion-Hart-Moore suggestion adds a valuable element because of their suggestion that bids for what to do at Stage 4 (or, on an alternative formulation, plans offered by those seeking to be elected as directors at Stage 4) be submitted already at Stage 2 before options need to be exercised. As will be explained below, having this information already at Stage 2 would help participants make their exercise decisions.

Let us conclude the description of how the procedure would operate by observing that it would streamline the insolvency process considerably. Compared with the existing bargainingbased process, the options procedure would get the company faster out of insolvency (with its associated financial distress costs) and into efficient decision-making. The proposed procedure would thus improve ex post efficiency. As we now turn to show, the procedure would also improve ex ante efficiency by implementing the contractually prescribed distribution.

\section{The Implementation of the Desired Distribution}

\subsection{Consistency with Participants' Entitlements}

Let us first show in the context of the simple example used above why no participant would have any basis for complaining about the outcome of the options procedure. Consider first the senior creditors. If they retain their type-1 rights until Stage 3, they will end up in one of two positions. First, their rights might be redeemed for 1 each, in which case they will be paid in full. Alternatively, their rights might not be redeemed, in which case they will end up with all the units of RC and thus would have no basis for complaining, as they would be getting the whole reorganization pie.

Consider now the junior creditors. If they retain their rights until stage 3 , they again will 
end up in one of two situations. First, their rights might be redeemed, in which case their claims will be paid in full. Alternatively, each junior creditor will have an option to purchase one unit of $\mathrm{RC}$ for 1 . And since the holder of each unit is never entitled to more than V/100-1, this option will make the value of $\mathrm{V} / 100-1$ accessible to the holder.

Finally, if the equityholders will retain their rights, they will have an option to purchase one unit of RC for 2 . And since each equityholder is never entitled to a positive value exceeding V/100-2, having the option would make this value accessible to the equityholder.

Turning to the more general case, let us consider a participant with an estimate $\mathrm{V}_{\mathrm{p}}$ of $\mathrm{V}$ that, without loss of generality, holds one unit of participation in class i. Using $\mathrm{V}_{\mathrm{p}}$ for $\mathrm{V}$, observe that the participant is entitled, according to his own estimate of $\mathrm{V}$, to a value of

$$
E_{p}=\left(1 / m_{i}\right) \min \left[D_{i}, \max \left(O, V_{p}-\bar{D}_{i}\right)\right] .
$$

Let us now show that the participant will never have any basis for complaining about getting less than this value. If $V_{p} \leq \bar{D}_{i}$, then the participant is entitled to 0 . Of course, the participant will always get no less than 0 under the proposed method. Now if $V_{p}>\bar{D}_{i}$ then the participant is entitled to get $E_{p}=\left(1 / m_{i}\right) \min \left[D_{i}, \max \left(O, V_{p}-\bar{D}_{i}\right)\right]$. However, by submitting the participant's option for exercise, and assuming $\mathrm{V}=\mathrm{V}_{\mathrm{p}}$, the participant will be able to get at least

Proposition : For any estimate $\mathrm{V}_{\mathrm{p}}$ that any given participant has of $\mathrm{V}$, the options procedure will provide the participant with a value that does not fall below the value to which the participant is entitled, using the participant's own estimate $V_{p}$ of $V$, according to the contractually specified distribution.

Note that, while the participant will never get less than $E_{p}$ - the value to which the participant is entitled given the participant's own estimate of $\mathrm{V}$ - the participant might end up 
with more than $\mathrm{E}_{\mathrm{p}}$. This might happen in the event that other participants have higher estimates of $\mathrm{V}$ than $\mathrm{V}_{\mathrm{p}}$. In such a case, the participant might end up with his right redeemed or purchased in the market for a value exceeding that to which the participant is entitled assuming that $\mathrm{V}$ is equal to $\mathrm{V}_{\mathrm{p}}$.

Note also that a potentially attractive feature of the options procedure is its decentralized nature. Participants will not be acting as classes with all the coordination and collective action problems involved in action by class. Rather, each participant will make his own decision as to what to do with his options and will be able to act on his own estimate of V. To be sure, participants will be allowed to coordinate and acquire information collectively, and they would be able to rely on the estimates provided by the market trading in the options. But they would not have to do so and would be free to act on the basis of whatever estimate of V they have.

\subsection{Problems of Liquidity and Information}

(i) Liquidity constraints. One objection that has been raised to the options procedure is that, to exercise the options, participants other than the most senior creditors might need to invest additional capital. And to the extent that such participants are liquidity constrained, they might be denied their contractual entitlement. This problem indeed might cause the procedure to implement the desired distribution imperfectly. But in assessing the significance of this problem, the following qualifications need to be taken into account. First, in the case of reorganization of publicly traded companies, most of the participants might hold only a small fraction of their portfolio in claims or shares of the reorganized company, and the problem of liquidity constraints thus might not be widespread. Second, even a liquidity-constrained participant might be able to get sufficient funds for exercising his options by pledging the purchased units of $\mathrm{RC}$ as a 
collateral. For example, suppose that in the used example, a junior creditor estimates $V$ to be 170 , but the market estimates $\mathrm{V}$ to be 150 and type- 2 options thus trade at 0.5 ; in such a case, the junior creditor will be able to borrow the 1 needed to exercise his option by pledging the bought unit of RC as a collateral. Finally, observe that in the worst-case scenario a liquidity-constrained participant still would be able to sell his options in the market. This implies that even in the worst-case scenario the participant would not fare worse than how the participant would fare if the assets were sold in an auction.

(ii) Another objection that has been raised is that, to work, the options procedure requires that participants have a lot of information about $\mathrm{V}$ on which to base their exercise decisions. In evaluating this objection, note first that the procedure does not increase the participants' need for information about $\mathrm{V}$; under the existing bargaining-based process, classes would also have to bargain on he basis of whatever estimate of $\mathrm{V}$ they have. It has been suggested that the bargaining process generates information about $\mathrm{V}$ because the committee representing each class can acquire information about $\mathrm{V}$. But if there are some efficiencies to acquiring information as a class rather than individually, the proposed procedure would not prevent the formation for each class of a committee that (perhaps with the help of an investment banker) will acquire information about $\mathrm{V}$ and disseminate it to class members. Indeed, under the options procedure, participants would have an important additional source of information about $\mathrm{V}$ - the market trading in the options. Furthermore, as noted earlier, additional information might be provided by requiring that managerial teams seeking to be elected to run the company at Stage 4 or buyers seeking to acquire it at Stage 4 submit their proposals already at Stage 2. Finally, note that a participant that a participant that would be still uninformed would always be able to sell his options in the market and thus still would never fare worse than in an auction of the company. 
5. Relationship to the Black-Scholes Characterization of Securities as Options

It would be worthwhile to relate the options approach to corporate bankruptcy to the approach put forward by the seminal paper of Black and Scholes (1972) (B-S). B-S pointed out that any corporate security can be viewed as equivalent to a certain option (or a set of options) with respect to the company's assets -- and can be accordingly valued using the B-S option pricing formula.

Consider a company that is formed at $\mathrm{T}=0$ with two classes: there are 100 equityholders each holding one share; and there are 100 debtholders each owed 1 which is due at $\mathrm{T}=1$. Let us denote by $\mathrm{V}$ the total value of the company's assets at $\mathrm{T}=1$. B-S implicitly assumed that, when time $\mathrm{T}=1$ arrives, the shareholders will get the value of $\mathrm{V}-100$ if $\mathrm{V}>100$ and zero otherwise (with the remainder in both cases going to the debtholders). Given this assumption, the shareholders will have at $\mathrm{T}=1$ an option to get $\mathrm{V}$ for an immediate exercise price of 100 . The value of this option at $\mathrm{T}=1, \mathrm{~B}-\mathrm{S}$ assumed, is straightforward: $\max (\mathrm{V}-100,0)$ for the shareholders as a whole or max $(\mathrm{V} / 100-1,0)$ per share. While $\mathrm{B}-\mathrm{S}$ assumed that valuing this option at $\mathrm{T}=1$ is straightforward, they focussed on the question of placing a value on this option (i.e., the share of the company) prior to $\mathrm{T}=1$, when the asset value $\mathrm{V}$ is following a random process and its ultimate value $\mathrm{V}$ at $\mathrm{T}=1$ is not yet known. This feature is the one that made difficult the valuation problem - which B-S sought to solve with their pricing formula.

In the B-S analysis, then, it was assumed that, at $\mathrm{T}=1$, value will be partitioned in accordance with the contract between debt and equity -- the equityholders will get max[V/100$1,0]$ each and the debtholders will get $\min (1, \mathrm{~V} / 100)$ each. The problem on which B-S focused was limited to valuing these claims prior to $\mathrm{T}=1$. Essentially, B-S assumed that the "legal 
technology" is perfect enough so that the contract between the equity and debt will be enforced at $\mathrm{T}=1$ in a way that would split $\mathrm{V}$ according to the "contractual partition." This would indeed be the case if $\mathrm{V}$ were verifiable; with verifiable $\mathrm{V}$, courts would have no problem implementing the contractual partition at $\mathrm{T}=1$.

But the legal technology under the existing legal rules is not perfect in this way. As Section 2 highlighted, V is not verifiable and, if the company files for Chapter 11 , V will be partitioned by bargaining that might produce a division that differs from the contractual partition. Thus, under the existing rules, when $\mathrm{T}=1$ arrives, the shareholders might end up with a value different than max $(\mathrm{V} / 100-1,0)$ each and the debtholders might get a value different than min $(1, \mathrm{~V} / 100)$ each. For example, equityholders might be able to extract some value even if $\mathrm{V}$ is less than 100 .

Note that the above observation implies that, under the existing rules, it would not be accurate to value shares prior to $\mathrm{T}=1$ by using the $\mathrm{B}-\mathrm{S}$ formula and assuming that at $\mathrm{T}=1$ each share will have a value of $\max [(\mathrm{V} / 100-1), 0]$. Rather, it is necessary to figure out what amount the shareholders will be able to extract at the bargaining at $\mathrm{T}=1$ bargaining, and then to plug this $\mathrm{T}=1$ amount into the option pricing formula.

The proposed options procedure seeks to ensure that the value at $\mathrm{T}=1$ will be divided according to the contractual partition, as B-S assumed that will happen but as might often not happen under the existing rules. That is, the options approach seeks to improve the legal technology that would be used for implementing the contractual partition. To do so, the options approach starts, as did B-S, from the observation that the value that the equityholders should get at $\mathrm{T}=1$ is equal to the value of an option to get $\mathrm{V}$ for an immediate exercise price of 100 . But rather than making use of this observation to value the equity at times prior to $\mathrm{T}=1$, the option 
procedure uses this observation to provide the equityholders with the value to which they are entitled at $\mathrm{t}=1$. While in the $\mathrm{B}-\mathrm{S}$ analysis the equivalence of securities to options was just a tool for calculation, the option procedure under consideration suggests that bankruptcy be done by actually writing out the options to which the value of the shares is equivalent, replacing the shares with such options written with respect to a clearing agent in the way described above, and letting the shareholders make their own decisions with respect to the options. In such a way, we have seen, it is possible to overcome the problem arising from the nonverifiability of V by courts and to implement the contractual partition at $\mathrm{T}=1$.

In essence, the recognition that the value to which any security holders are entitled at $\mathrm{T}=1$ can be characterized as an option enables us to implement the contractual division of value at $\mathrm{T}=1$ even when $\mathrm{V}$ is not verifiable and courts could not divide value according to the contractual partition. As the analysis above has shown, this division could be implemented by actually writing out the options and distributing them to participants. In other words, the recognition that all corporate securities can be viewed as options on the company's assets can be used to make the contractual partition of value self-enforcing and one that does not require that the value of the assets be ever verifiable by courts. The recognition that securities can be viewed as options, then, can be used not only as a tool for calculating the worth of securities prior to the date in which the value of the assets must be partitioned, but also as a tool for improving the technology by which the value of the assets will be divided.

\section{Conclusion}

The options approach offers an attractive alternative to the bargaining-based approach of existing rules. By moving the company quickly out of insolvency proceedings and into efficient 
decision-making about the assets, the options procedure would improve ex post efficiency. And by overcoming the valuation problem and implementing the distribution of value prescribed by participants' contractual entitlements, the procedure would improve ex ante efficiency. 


\section{REFERENCES}

Aghion, P., O. Hart, and J. Moore (1992), "The Economics of Bankruptcy Reform," Journal of Law, Economics, and Organization, Vol. 8, pp. 527 -.

Baird, Douglas (1986), "The Uneasy case for Corporate Reorganizations," Journal of Legal Studies, Vol. 15, pp. 127.

Bebchuk, Lucian (1988) "A New Approach to Corporate Reorganizations," Harvard Law Review, Vol. 101, 775-804.

and H. Chang (1992), "Bargaining and the Division of Value in Corporate Reorganization," Journal of Law, Economics, and Organization, Vol. 8, pp. 253-279.

---------(1998a), “Chapter 11,” in The New Palgrave Dictionary for Law and Economics.

(1998b), “A Generalization of the Options Approach to Corporate Reorganization," paper presented at the American Law and Economics Association 1998 meeting.

---------(1999), “The Options Approach to Corporate Bankruptcy," Harvard Law School, manuscript in preparation.

Black, F. and M. Scholes (1972), "The Pricing of Options and Corporate Liabilities," Journal of Political Economy, Vol. 81, 637-654.

Cutler, D.M. and L.H. Summers (1988), "The Costs of Conflict Resolution and Financial Distress: Evidence from the Texaco-Pennzoil Litigation," Rand Journal of Economics, Vol. 19, 157-72.

Eberhart, A.C., Moore, W.T., and R.L. Roenfeldt (1990), "Security Pricing and Deviations from the Absolute Priority Rule in Bankruptcy Proceedings," Journal of Finance, Vol. 45, 1457-69. Franks, J.R. and W.N. Torous (1989), "An Empirical Investigation of U.S. Firms in Reorganization," Journal of Finance, Vol. 44, 747-69.

Gilson, S., Kose, J., and L. Lang (1990), "Troubled Debt Restructuring: An Empirical Study of Private Reorganization of Firms in Default," 27 Journal of Financial Economics, Vol. 27, pp. 315-53.

Hart, O. (1995), Firms, Contracts, and Financial Structure (Oxford University Press).

Hart, Oliver, Rafael LaPorta, Florencio Lopez-de-Silanes, and John Moore (1997), “A New Bankruptcy Procedure that uses Multiple Auctions," European Economic Review 41, 461-473. 
Hotchkiss, E. (1995), "Postbankruptcy Performance and Management Turnover," Journal of Finance, Vol. 50, pp. 3-21.

Jensen (1991), "Corporate Control and the Politics of Finance," Journal of Applied Corporate Finance, Vol. 4, pp. 13-33.

Shleifer, A. and R. Vishny (1992), " Liquidation Value and Debt Capacity: A Market Equilibrium Approach," Journal of Finance, Vol. 47, 4.

Weiss, L.A. (1990), "Bankruptcy Resolution: Direct Costs and Violation of Priority of Claims," 27 Journal of Financial Economics, Vol. 27, pp. 285-314. 